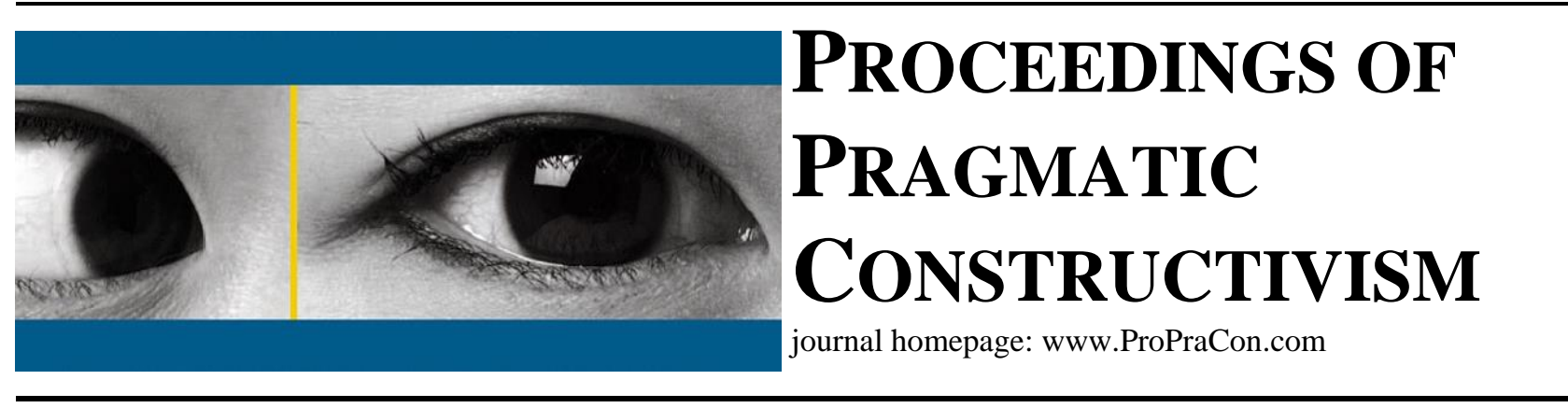

\title{
Integration of Risk Management into Management Control System from a Pragmatic Constructivist Perspective
}

\author{
Magdalena Janiak \\ Aarhus University \\ Bartholins Allé 10, 8000 Aarhus C, Denmark; magdalena.janiak.89@gmail.com
}

\begin{abstract}
The idea of the paper is to inform risk management (RM) with the pragmatic constructivist (PC) perspective, and to simultaneously integrate risk management with management control systems (MCS) bearing in mind that the key to the PC perspective is that risk information has both subjective and objective components. The paper will (1) Show how to improve Risk Management systems using the Pragmatic Constructivist perspective. (2) Demonstrate how to use the Pragmatic Constructivist perspective to integrate Risk Management into Management Control Systems. (3) Provide a case study to apply the theory by showing how Management Control System can govern Risk Management from Pragmatic Constructivist perspective. Applying the case study finds out mainly that action control in a form of two-way communication between actors (managers and technicians) at the process of risk identification, risk analysis, decision making and monitoring, risk reality is necessary. Results controls direct attention to facts entered by actors according to their expertise and level of influence. Personnel control enables to choose people with common values and necessary competencies to share knowledge for risk management. In this way actor-based reality with the actors being co-authors of the reality can take place. The main implications of the research suggest that: 1) the successful integration of RM into MCS requires pragmatic constructivist reality to applied by providing the contribution from all the actors so that the RM system is practical, and 2) RM should be designed to gather some subjective data from the ground level (e.g. on the probability of an incident recurring and the potential costs of any particular type of incident) to balance the objective information gathered so that the PC approach can support RM and MCS.
\end{abstract}

Keywords: Performance measurement; KPIs; risk management; pragmatic constructivism; actor reality construction. 


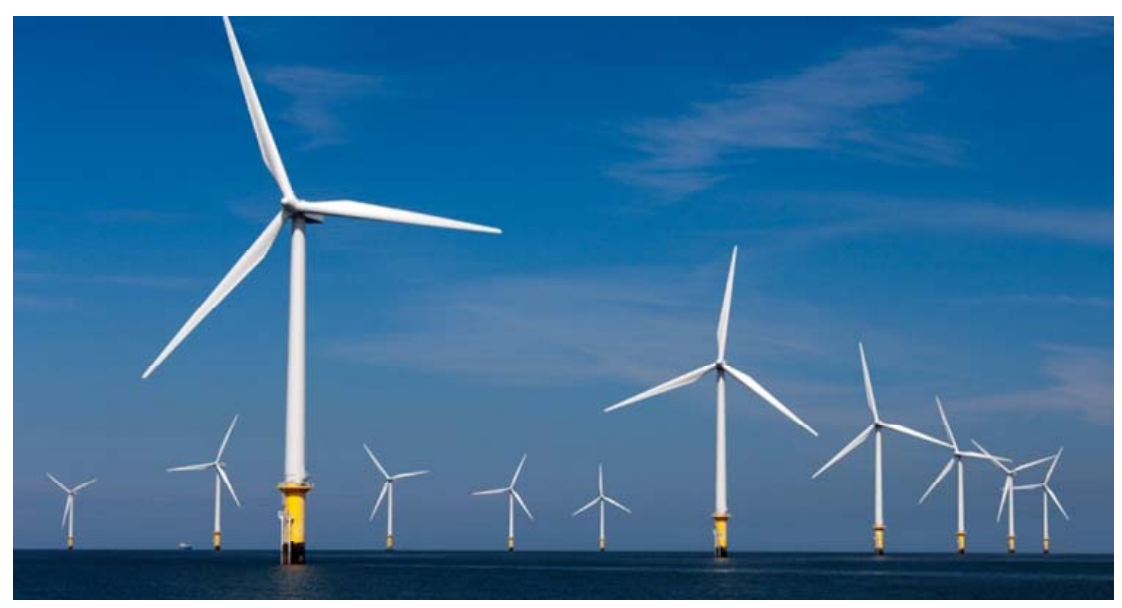

TOPIC: Integration of Risk Management into Management Control System from a Pragmatic Constructivist Perspective

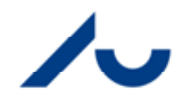

AARHUS UNIVERSITY

PRESENTATION OUTLINE

AGENDA | presentation structure

Introduction

Approach

Problem of the research and objectives

Theoretical background

Risk management system as a part of MCS

Data collection and analysis

Findings and implications 


\section{INTRODUCTION}

- ZERO HARM campaign

- Proactive reporting - near -misses

- Tool to support risk management

- Management control problems

\section{APPROACH}

- Objectivist (objective) perspective ignores the social processing of risk information.

- Constructivist (subjective) perspective may lead to more fatalities.

(The issue here is whether technical risk estimates represent 'objective' probabilities of harm or reflect only conventions of elite group).

An actor-based approach is applied which contributes to the understanding of PC (pragmatic constructivism expresses the successful relationship between the actors) by focusing on the employees' (actors) - the co-authors of a common reality. 


\section{PROBLEM OF THE RESEARCH AND OBJECTIVES}

How can applying Pragmatic Constructivism to understand the process of Risk Management facilitate the use of MCS for Risk Management?

Show how to improve Risk Management systems using the Pragmatic Constructivist perspective.

Demonstrate how to use the Pragmatic Constructivist perspective to integrate Risk Management into Management Control Systems.

Provide a case study to apply the theory by showing how Management Control System can govern Risk Management from Pragmatic Constructivist perspective.

\section{THEORETICAL BACKGROUND}

- Risk and risk management

- Management Control System

- Pragmatic Constructivism 
Input: Identifying risk and implications

Process: Analysing risk and evaluating risk, prioritizing risk

Output: Risk must be monitored to ensure that action plans are progressing properly and that hazards that are triggering risk are managed.

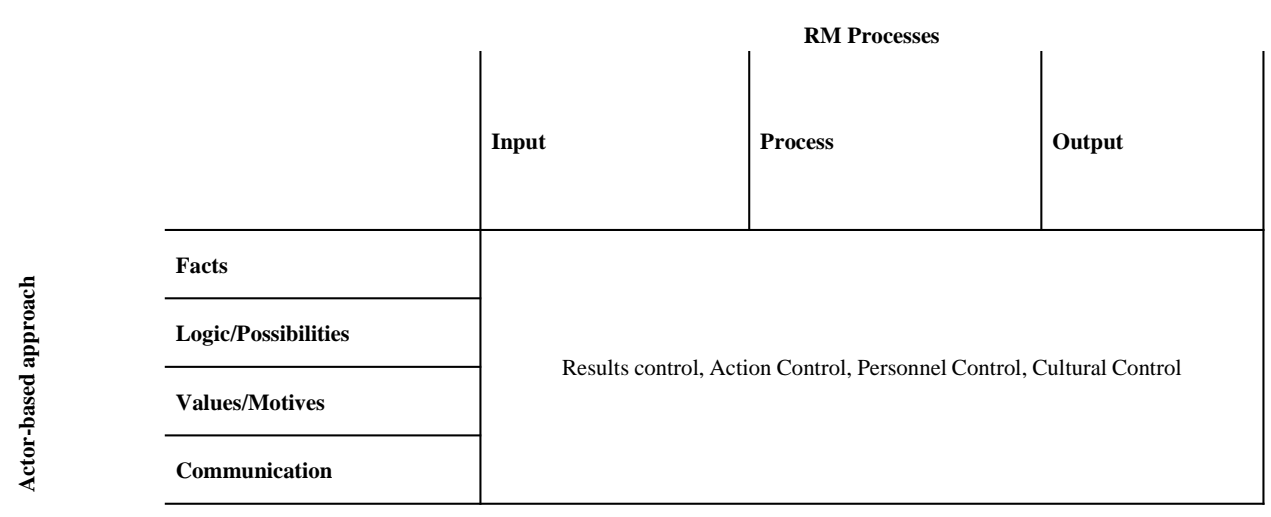

Introduction $\rangle$ Approach $\left.\left.\sum \begin{array}{c}\text { Problem and } \\ \text { objectives }\end{array}\right\rangle \begin{array}{c}\text { Theoretical } \\ \text { background }\end{array}\right\rangle$ KRIMA system $\left.\rangle \begin{array}{c}\text { Data collection } \\ \text { and analysis }\end{array}\right\rangle \begin{gathered}\text { Findings and } \\ \text { implications }\end{gathered}$

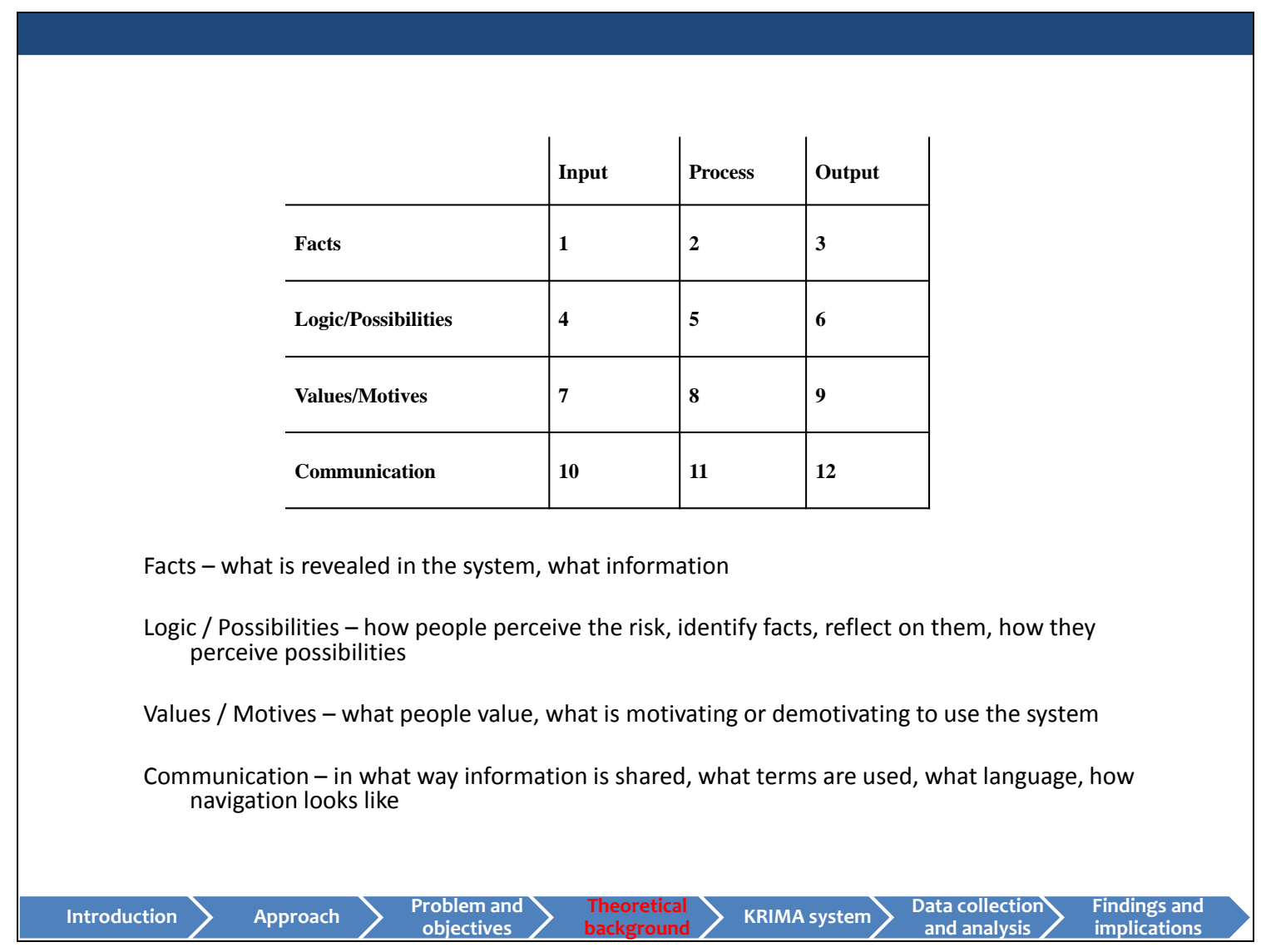




\section{Risk management system}

\begin{tabular}{|c|l|l|}
\hline 1. Event notification & \multicolumn{1}{|c|}{ 2. Workflow } & 3. Analyse and monitor \\
\hline Reporting a near-miss event & $\begin{array}{l}\text { Processing/analysing the } \\
\text { workflow related to the event by } \\
\text { the responsible manager }\end{array}$ & $\begin{array}{l}\text { Analysing events together and } \\
\text { preparing reports and trends }\end{array}$ \\
\hline
\end{tabular}

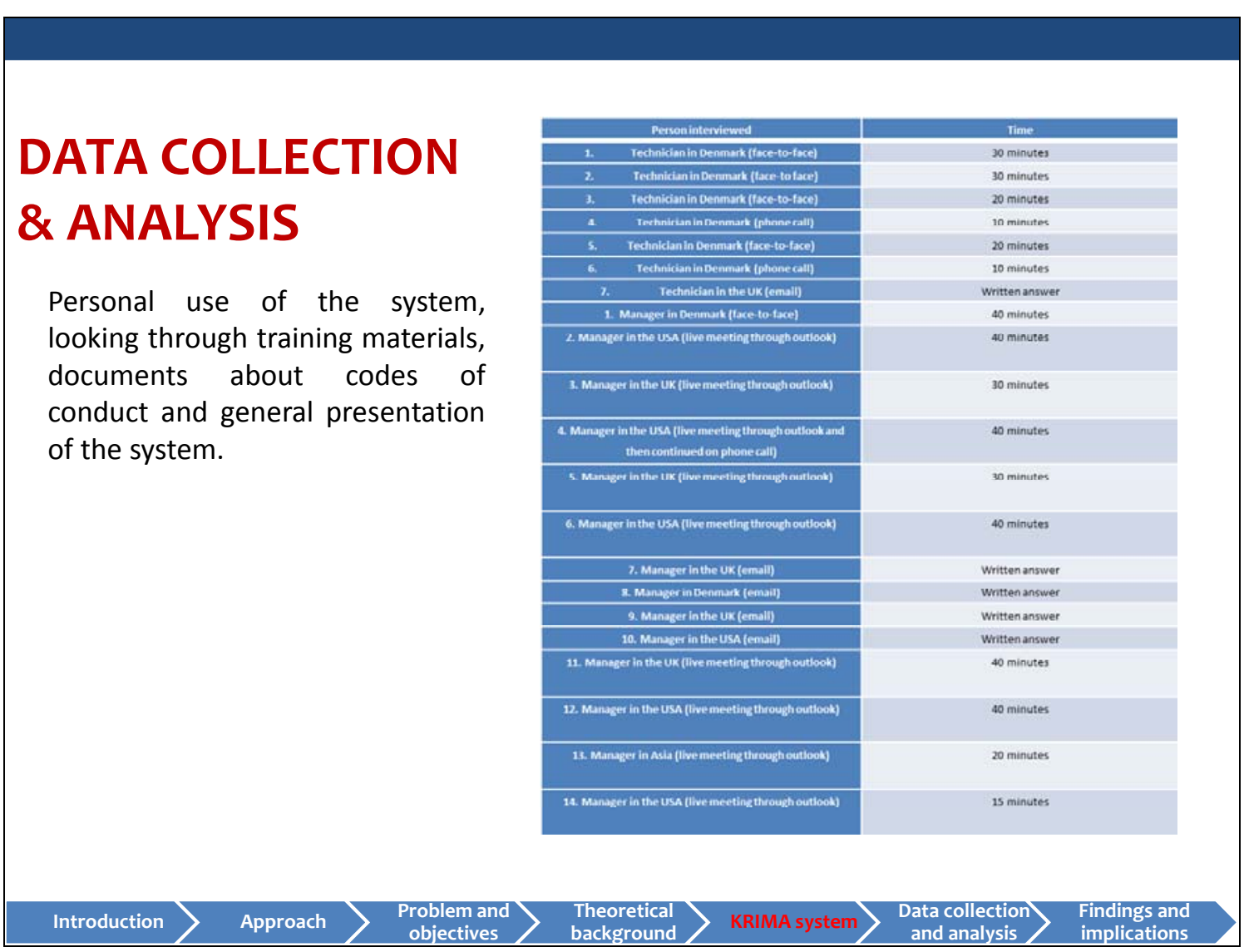




\section{DATA COLLECTION}

\& ANALYSIS

\section{Questions posed in a form of semi- structured interviews \& questionnaires were used to:}

- Clarify the issues

- Understand problems from different perspectives

- Get information not known before

- Grouping the quotes

Introduction $\sum$ Approach $\left.\left.\sum \begin{array}{c}\text { Problem and } \\ \text { objectives }\end{array}\right\rangle \begin{array}{c}\text { Theoretical } \\ \text { background }\end{array}\right\rangle$ KRIMA system $\left.\rangle \begin{array}{c}\text { Data collection } \\ \text { and analysis }\end{array}\right\rangle \begin{gathered}\begin{array}{c}\text { Findings and } \\ \text { implications }\end{array} \\ \text { and }\end{gathered}$

\section{Facts}

- Input (identification)

- System can be designed in a way to enable local information to be put in, and not predefined by top management, for example in a form of empty boxes for new information to be filled in and approved. Otherwise, data may not be usable.

After being asked what facts are relevant and what the problems are they say:

Technician: "Turbine number, our name, what has happened... (p. 9, I. 29)"

Manager: "Correctly, we are always having things fabricated here locally, to fit what we need to do because they just don't make the tool. They want to do something with the tool but the tool is not available. I can feel something if you start saying "hey, we use this fabricated thing, ......we are using this but while using this I slept". It had nothing to do with the tool but then globally they are saying "hey, we have a need for this particular tool or we can start making a better tool , we can provide what we actually need through the data of the system." (p. 24, I. 18) 


\section{Facts}

- Process (analysis, evaluation, prioritizing, decision making)

- Appropriate decentralization of duties is required to make sure that people handling the case are able to make risk assessments and identify all causal factors and make decisions. In order to do that responsible people could be risk owners and system platform could provide guidelines and access to experts who can provide valid data after common discussion.

- It could be also helpful to make it clear which facts are subjective and which are objective, making it possible to reveal technical computations of assessment and subjective assessments of people and display it as a fact in the output workflows.

Manager: "[...]it shouldn't land on my desk; that should be handled by those guys. Let's say that a new unit was committed to using the system. Then, they would get reports from somebody like me in Denmark, saying 'oh, we have this problem, you have to solve it in the task' .... [T] hen, they would look at me...; why does this come from Denmark; this is a universal problem, on all 2.3 turbines?" (p. 18, I. 1)

Manager: "Sometimes, we have to settle for causal factors, which may or may not lead us to the true hazard influence." (p. 35, I. 17)

Introduction $\sum$ Approach $\left.\sum \begin{array}{c}\text { Problem and } \\ \text { objectives }\end{array}\right\rangle \begin{array}{c}\text { Theoretical } \\ \text { background }\end{array} \sum$ KRIMA system $\left.\left.\rangle \begin{array}{c}\text { Data collection } \\ \text { and analysis }\end{array}\right\rangle \begin{array}{c}\text { Findings and } \\ \text { implications }\end{array}\right\rangle$

\section{Facts}

- $\quad$ Output (monitoring)

The output platform consists of the facts that have been altered or left unchanged by the managers in the input notifications and in the process workflows. All facts, new or old, that have survived to that point are available in the final workflows.

Manager: "I think system was made [because] somebody needed some statistics and kind of made a list of this statistic and that statistic, and then, they made a system that could generate those statistics. That's how I look at it. Afterwards, the whole user interface is just an afterthought" (p. 16, I. 24) 


\section{Logic / Possibilities}

\section{- Input (identification)}

- Identify opportunities in the system before the information appears in the workflow

- Action Control: a discussion platform > dealing with risk perceptions and identifying uncertainties

Technician: "I don't know how many hundreds or thousands of system reports are from the USA or Germany; they report everything, like a flat tire [...], stuff like this. If you report all these things, then the system is overloaded, and then, the actual issues disappear." (p. 4, I. 8)

Manager: "I know that there has been a discussion among people that somebody was reported to be sea sick, and the question was, should that really be a report? When people are travelling, there have been specific incidents when people have reported in system..., and we were thinking whether it should have really been reported."

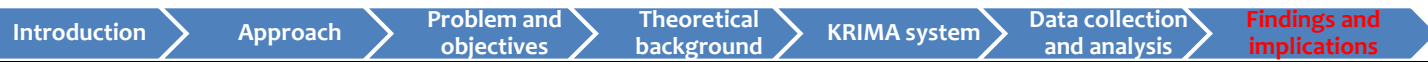

\section{Logic / Possibilities}

- Process (analysis, evaluation, prioritizing, decision making)

- Due to no interaction in the system, process of analysis seems to be random according to individual perceptions and different opinions influence the possible solutions in different workflows. Since there are not commonly agreed possibilities identified in the input, there are problems identifying solutions that might be significant for others.

- Guidelines may not be enough for risk assessments, since they can be understood in a different way (people have different experiences and expertise). Grouping of people and separation of duties can help to make sure that analysis done by manager is approved by others.

- Personnel control in a form of trainings and selection of people is not sufficient.

Manager: "We are counting on employees that understand very little about the system and very little about incident investigation to provide the data we may be looking for." $(p .34,1.18)$

Manager: "Well, and as for the 'lessons learned,' there is no standard answer for that field. (...)[W]e want to put something there; sometimes it's a good thing; sometimes it's a bad thing. It may have no relevance to work, such as there's 'a deer in front of the car,' and the lessons learned are 'slow down' and 'pay attention while driving'. That has no relevance to work." (p. 29, I. 12)

Manager: "As far as getting to the root cause is concerned, you use one of the systems like a taproot-I mean the simpler ones, like a flow chart system-to see if it is likely and give a number to it and then see if it's going to be minimal to severe, to see what that level is." (p. 22, I. 19)

Manager: "Likelihood is a little more of a grey area when we think in terms of 'unlikely' or 'possible'." $(p .35,1.23)$ 


\section{Logic / Possibilities}

\section{- Output (monitoring)}

Manager: "My trend analysis is more simplistic. I use a trend analysis to produce graphs for how many incidents we've had, how many closed system reports we've had, and how many incidents we've had in different areas, and then we focus on a campaign for that particular area." (p. 27, I. 4)

One manager even says:

Manager: "Maybe some trends could be established globally."(p. 47, I. 11)

In order to identify possibilities in risk management, results control can ensure that it is the number of risk factors and effective decisions made that lower risk that matter most, not the time to close the workflow.

Action control defining which trends are shared (between the actors) could make it possible to share knowledge about regional or global problems and possible solutions within output platform and not in the spreadsheets outside the system since knowledge is not easily shared and widely available this way.

\section{Values / Motives}

\section{- Input (identification)}

Technician: I made a lot of system and informed our EHS officer about it a lot of times and he promised me that there will be another system, easy to use. (p. 9, I. 21)

Technician: We fix the problem the way we think is best. Sorry. We take care of ourselves every day. (p. 4, l. 2)

Technician: It would be nice to know if there was a specific problem with the tool, or the turbines, or the site or the picture of the item going bad and send it to all technicians. (p.7, I. 32)

Because the people who deliver facts to the system are technicians who value their safety, they know which facts are relevant and necessary to report. It indicates why near-miss notifications, i.e., notifications of close calls of potential accidents, are still used in the system. However, there is no feedback from the system and therefore, lower motivation to submit information to the system. 


\section{Values / Motives}

- Process (analysis, evaluation, prioritizing, decision making)

Manager: "I do what I have to do to close the report ...; when it is closed, nobody cares if I actually reduced the residual risk on paper. What matters is when I actually talk to technicians and explain to them 'don't do this and this." (p. 18, I. 11)

Manager: "Since it is not providing me with a tool to come up with a cause or anything related to that, the reason for the system in my life is that 'I am told what I am supposed to use and do'." (p. 25, I. 2)

Action control seems to be needed to enable discussion among managers and a 'guided tour', and there is no mutual interest how to decrease the risk within the system, selection of one manager to handle the workflow acts against his values. This results in a purely record keeping function of the system, which nobody checks. 


\section{Communication}

- Input (identification)

Manager: "Because there are no rules for free text editing and headers-for example-the notifications often lack much 'WH-information."' ( $p .41,1.5)$

Manager: "[I]t is quite time consuming for me to find three previous incidents in the system that are related to oil in the spinner, but that sort of trend analysis is great to look at. Then, we think 'Maybe we need to look at what the equipment is.' I don't think KRIMA pulls that out very well." (p. 26, I. 18)

Technician: "What is that? Subcontractor? And Business Unit? Inside/outside? I don't understand what it means. Well... you have to report all these tasks? ...hmm, customer? When there is a star, I guess I have to put it in? Affected and involved? What is the difference? Am I from the responsible segment? It's too much to choose in the template. [] It would be nice if the template were adjusted to the site you chose or the turbine." (p. 8, I. 9))

In order to get understanding of knowledge shared, frequent contacts can help. Action control could provide a discourse between the actors how to define terminology to share knowledge. Properly defined terminology could be later remembered by the system. Another solution is results control by updating a list of new facts appearing in the system. Terminology needs to understood by the actors. Therefore, it is important who updates information for statistics.

\section{Communication}

- Process (analysis, evaluation, prioritizing, decision making)

Manager: "I do what I have to do to close the report ...; when it is closed, nobody cares if I actually reduced the residual risk on paper. What matters is when I actually talk to technicians and explain to them 'don't do this and this.'" (p. 18, I. 8)

The information entered could be verified by other experts and compared against what is collected already in other reports. Action control could ensure that the problem related to the turbine work is resolved or to determine whether an investigation is necessary. Personnel control could be introduced by introducing and identifying experts for event to be dealt with. 


\section{Values / Motives}

- Output (monitoring)

Manager: "We share information with customers in case they need some information. We analyse trends according to customers. The topics are types of incidents or specific incidents." (p. 33, I.13)

Action control in a form of feedback on the effectiveness of decisions and sharing doubts and nuances in a common platform could help in sharing ideas on lowering risk.

\section{Summary of findings}

- Facts show that is important to define where knowledge is in order to define up-to-date, most valid information about risk factors, decisions, risk assessments, etc.

- Logic/Possibilities show that people need to cooperate and create a transparency in terms of analysis to make sure that the way factual possibilities are identified is commonly accepted and uniform different risk perceptions.

- Values/Motives show that without mutual monitoring and feedback, the information gathered will not be usable or will not be coming at all.

- Communication shows that defining experts who understand specific terminology, language, IT can contribute to the system and use it. Otherwise, information will not be usable or it will come too late. 


\section{Implications}

The successful integration of RM into MCS requires input from the ground level (in this case- technicians and line managers) so that the RM system is practical for all the actors who use the system to manage risk proactively. Therefore controllability should be designed to gather some subjective data from the ground level (e.g. on the probability of an incident recurring) to balance the objective information gathered so that the PC approach can support RM and MCS. 


\section{References}

Abernethy, M. A., \& Brownell, P. 1997. Management control systems in research and development organizations: The role of accounting, behavior and personnel controls. Accounting, Organizations and Society, 22(3-4): 233-248.

Ahrens, T., \& Chapman, C. S. 2007. Management accounting as practice. Accounting, Organizations and Society, 32(1-2): 1-27.

Albertsen, O. A., \& Lueg, R. 2014. The Balanced Scorecard's missing link to compensation: a literature review and an agenda for future research. Journal of Accounting and Organizational Change, 10(4): 431-465.

Alhawari, S., Karadsheh, L., Talet, A. N., \& Mansour, E. 2012. Knowledge-based risk management framework for information technology project. International Journal of Information Management, 32(1): 50-65.

Ancelin-Bourguignon, A. 2012. Getting out of mechanical management: lessons from Chinese thought. Proceedings of Pragmatic Constructivism, 2(1): 3-9.

Andersen, T. J. 2008. The performance relationship of effective risk management: Exploring the firm-specific investment rationale. Long Range Planning, 41(2): 155-176.

Anthony, R. N. 1965. Planning and Control Systems: A framework for Analysis. Boston, MA: Harvard Business School Press.

Baldvinsdottir, G., Johansson, I.-L., \& Nørreklit, H. 2011. Actor-based management - The TESCO way. In M. Jakobsen, I.-L. Johansson, \& H. Nørreklit (Eds.), An Actor's Approach to Management: Conceptual Framework and Company Practices: 75-98. Copenhagen: DJOEF.

Berry, A. J., Coad, A. F., Harris, E. P., Otley, D. T., \& Stringer, C. 2009. Emerging themes in management control: a review of recent literature. The British Accounting Review, 41(1): 2-20.

Beusch, P. 2012. Highlighting the complex interrelationship between the concepts of trust and control. Proceedings of Pragmatic Constructivism, 2(2): 33-50.

Boer, N.-I. 2005. Knowledge Sharing Within Organizations. Rotterdam: Erasmus Research Institute of Management (ERIM).

Borisov, B. G., \& Lueg, R. 2012. Are you sure about what you mean by ‘uncertainty’? The actor’s perspective vs. the institutional perspective. Proceedings of Pragmatic Constructivism, 2(2): 51-58.

Bourdieu, P., \& Passeron, J.-C. 1977. Reproduction in Education, Society and Culture. London: Sage.

Brunsson, N. 1989. The Organization of Hypocrisy: Talk, Decisions and Actions in Organizations. New York, NY: Wiley.

Burkert, M., \& Lueg, R. 2013. Differences in the sophistication of Value-based Management - The role of top executives. Management Accounting Research, 24(1): 3-22.

Chenhall, R. H. 2003. Management control systems design within its organizational context: findings from contingency-based research and directions for the future. Accounting, Organizations and Society, 28(2-3): 127168.

Cinquini, L., Falconer, M., Nørreklit, H., \& Tenucci, A. 2012. Methodologies for managing performance measurement. In F. Mitchell, H. Nørreklit, \& M. Jakobsen (Eds.), The Routledge Companion to Cost Management: 342-359. New York, NY: Routledge.

Cinquini, L., Tenucci, A., Campanale, C., \& Passetti, E. 2013. Understanding performance measurement in public organization under pragmatic constructivism. Proceedings of Pragmatic Constructivism, 3(1): 3-22.

Collier, P. M., \& Berry, A. J. 2002. Risk in the process of budgeting. Management Accounting Research, 13(3): 273297.

Czarniawska-Joerges, B., \& Jacobsson, B. 1989. Budget in a cold climate. Accounting, Organizations and Society, 14(1-2): 29-39.

Davenport, T. H., \& Prusak, L. 1998. Working Knowledge: How Organizations Manage What They Know. Boston, MA: Harvard Business Press.

Ditillo, A. 2004. Dealing with uncertainty in knowledge-intensive firms: the role of management control systems as knowledge integration mechanisms. Accounting, Organizations and Society, 29(3): 401-421.

Ditillo, A. 2012. Designing management control systems to foster knowledge transfer in knowledge-intensive firms: A network-based approach. European Accounting Review, 21(3): 425-450.

Farrelly, G. E., Ferris, K. R., \& Reichenstein, W. R. 1985. Perceived risk, market risk, and accounting determined risk measures. The Accounting Review, 60(2): 278-288.

Feldman, M. S., \& Orlikowski, W. J. 2011. Theorizing practice and practicing theory. Organization Science, 22(5): 1240-1253.

Ferreira, A., \& Otley, D. 2009. The design and use of performance management systems: An extended framework for analysis. Management Accounting Research, 20(4): 263-282.

Foucault, M. 1977. Discipline and Punish: The Birth of the Prison. London: Vintage. 
Grody, A. D., Hughes, P. J., \& Toms, S. 2010. Risk accounting-a next generation risk management system for financial institutions. Journal of Financial Transformation, 29(1): 43-56.

Hansen, M. T. 1999. The search-transfer problem: The role of weak ties in sharing knowledge across organization subunits. Administrative Science Quarterly, 44(1): 82-111.

Hansen, M. T. 2002. Knowledge networks: Explaining effective knowledge sharing in multiunit companies. Organization Science, 13(3): 232-248.

Huelsbeck, D. P., Merchant, K. A., \& Sandino, T. 2011. On testing business models. The Accounting Review, 86(5): 1631-1654.

IFAC. 2002. Competency Profiles for Management Accounting Practice and Practitioners. New York, NY: International Federation of Accountants, Financial and Management Accounting Committee.

Jack, L. 2014. Further explorations of possibilities, methodologies of the future and rogue traders. Proceedings of Pragmatic Constructivism, 4(2): 32-38.

Jakobsen, M., Johanson, I.-L., \& Nørreklit, H. (Eds.). 2011. An Actor's Approach to Management: Conceptual Framework and Company Practices. Copenhagen: DJOEF.

Jakobsen, M., \& Lueg, R. 2012. The Balanced Scorecard: the illusion of maximization without constraints. Proceedings of Pragmatic Constructivism, 2(1): 10-15.

Jakobsen, M., \& Lueg, R. 2014. Balanced scorecard and controllability at the level of middle managers - The case of unintended breaches. Journal of Accounting and Organizational Change, 10(4): 516-539.

Jarzabkowski, P. 2005. Strategy As Practice: An Activity Based Approach. Thousand Oaks, CA: Sage.

Jarzabkowski, P., \& Spee, A. P. 2009. Strategy-as-practice: A review and future directions for the field. International Journal of Management Reviews, 11(1): 69-95.

Jørgensen, B., \& Messner, M. 2010. Accounting and strategising: a case study from new product development. Accounting, Organizations and Society, 35(2): 184-204.

Kaplan, R. S., \& Norton, D. P. 2008. The Execution Premium: Linking Strategy to Operations for Competitive Advantage. Boston, MA: Harvard Business Press.

Klinke, A., \& Renn, O. 2002. A new approach to risk evaluation and management: Risk-based, precaution-based, and discourse-based strategies. Risk analysis, 22(6): 1071-1094.

Ko, K.-C. 2004. Prospect Theory and the Risk-Return Relationship: Evidence from Mutual Funds. Puli: National Chi Nan University - College of Management.

Laine, T., Cinquini, L., Suomala, P., \& Tenucci, A. 2013a. Roles of accounting in New Service Development within Servitization - The viewpoint of pragmatic constructivism. Proceedings of Pragmatic Constructivism, 3(2): 97110.

Laine, T., Suomala, P., \& Nørreklit, H. 2013b. NPD accounting: unveiling the potential through pragmatic constructivism. Proceedings of Pragmatic Constructivism, 3(1): 23-34.

Latour, B. 1987. Science in Action: How to Follow Scientists and Engineers through Society. Cambridge, MA: Harvard University Press.

Lueg, R. 2009. Führt der Einsatz externer Berater zur Überimplementierung innovativer Steuerungsinstrumente? Zeitschrift der Unternehmensberatung, 4(6): 249-253.

Lueg, R., \& Borisov, B. G. 2014. Archival or perceived measures of environmental uncertainty? Conceptualization and new empirical evidence. European Management Journal, 32(4): 658-671.

Lueg, R., Malinauskaite, L., \& Marinova, I. 2014. The vital role of business processes for a business model: the case of a startup company. Problems and Perspectives in Management, 12(4): 213-220.

Lueg, R., \& Nørreklit, H. 2012. Performance measurement systems - Beyond generic strategic actions. In F. Mitchell, H. Nørreklit, \& M. Jakobsen (Eds.), The Routledge Companion to Cost Management: 342-359. New York, NY: Routledge.

Lueg, R., \& Pedersen, L. D. 2014. How do controls and trust interact? The case of failed alliance negotiations in the financial services industry. International Journal of Business Research: forthcoming.

Malina, M. A., Nørreklit, H., \& Selto, F. H. 2007. Relations among measures, climate of control, and performance measurement models. Contemporary Accounting Research, 24(3): 935-982.

Malina, M. A., Nørreklit, H., \& Selto, F. H. 2011. Lessons learned: Advantages and disadvantages of mixed method research. Qualitative Research in Accounting \& Management, 8(1): 59-71.

Malmi, T., \& Brown, D. A. 2008. Management control systems as a package - Opportunities, challenges and research directions. Management Accounting Research, 19(4): 287-300.

Merchant, K. A., \& Van der Stede, W. A. 2011. Management Control Systems: Performance Measurement, Evaluation and Incentives (3rd ed.). Upper Saddle River, NJ: Prentice Hall.

Mikes, A. 2009. Risk management and calculative cultures. Management Accounting Research, 20(1): 18-40.

Miller, P., Kurunmäki, L., \& O’Leary, T. 2008. Accounting, hybrids and the management of risk. Accounting, Organizations and Society, 33(7): 942-967. 
Neef, D. 2005. Managing corporate risk through better knowledge management. Journal of The Learning Organization, 12: 112-124.

Nielsen, L. B., Mitchell, F., \& Nørreklit, H. 2015. Management accounting and decision making: two case studies of outsourcing. Accounting Forum, 39(1): 64-82.

Nixon, B., \& Burns, J. 2012. The paradox of strategic management accounting. Management Accounting Research, 23(4): 229-244.

Nørreklit, H. 2000. The balance on the balanced scorecard - a critical analysis of some of its assumptions. Management Accounting Research, 11(1): 65-88.

Nørreklit, H., Nørreklit, L., \& Mitchell, F. 2007. Theoretical Conditions for Validity in Accounting Performance Measurement. In A. Neely (Ed.), Business Performance Measurement. Cambridge: Cambridge University Press.

Nørreklit, H., Nørreklit, L., \& Mitchell, F. 2010. Towards a paradigmatic foundation for accounting practice. Accounting, Auditing \& Accountability Journal, 23(6): 733-758.

Nørreklit, H., Nørreklit, L., Mitchell, F., \& Bjørnenak, T. 2012. The rise of the Balanced Scorecard - Relevance regained? Journal of Accounting and Organizational Change, 8(4): 490-510.

Nørreklit, L. 2011a. Actors and reality: A conceptual framewok for creative governance. In M. Jakobsen, I.-L. Johanson, \& H. Nørreklit (Eds.), An Actor's Approach to Management: Conceptual Framework and Company Practices: 7-38. Copenhagen: DJOEF.

Nørreklit, L. 2011b. Actors and reality: a conceptual framework for creative governance. In M. Jakobsen, LillJohansson, \& H. Nørreklit (Eds.), An Actor's Approach to Management: Conceptual Framework and Company Practices: 7-38. Copenhagen: DJØF.

Nørreklit, L. 2013. Reality as a construct: outline of a pragmatic constructivist perspective. Proceedings of Pragmatic Constructivism, 3(2): 57-66.

Nørreklit, L., Nørreklit, H., \& Israelsen, P. 2006. The validity of management control topoi: towards constructivist pragmatism. Management Accounting Research, 17(1): 42-71.

Olsson, R. 2007. In search of opportunity management: Is the risk management process enough? International Journal of Project Management, 25(8): 745-752.

Otley, D. T. 1999. Performance management: a framework for management control systems research. Management Accounting Research, 10(4): 363-382.

Pidgeon, N. 1998. Risk assessment, risk values and the social science programme: why we do need risk perception research. Reliability Engineering \& System Safety, 59(1): 5-15.

Preyssl, C. 1995. Safety risk assessment and management - The ESA approach. Reliability Engineering \& System Safety, 49(3): 303-309.

Roslender, R., \& Hart, S. J. 2010. Taking the customer into account: transcending the construction of the customer through the promotion of self-accounting. Critical Perspectives on Accounting, 21(8): 739-753.

Ross, S., \& Westerfield, R. 2015. Fundamentals of Corporate Finance (11th ed.). New York, NY: McGraw-Hill.

Ryan, D., \& Wentzel, K. 2000. The influence of attributions and budget emphasis on framing and risk preferences under conditions of unfavorable budget variances, Advances in Accounting Behavioral Research: 133-152: Emerald Group Publishing Limited.

Schatzki, T. R. 1996. Social practices: A Wittgensteinian approach to human activity and the social: Cambridge Univ Press.

Seal, W. 2012. Some proposals for impactful management control research. Qualitative Research in Accounting \& Management, 9(3): 228-244.

Seal, W., \& Mattimoe, R. 2014. Controlling strategy through dialectical management. Management Accounting Research, 25(3): 230-243.

Simons, R. 1990. The role of management control systems in creating competitive advantage: New perspectives. Accounting, Organizations and Society, 15(1-2): 127-143.

Smith, P. G., \& Merritt, G. M. 2002. Proactive risk management: Controlling uncertainty in product development. New York, NY: Productivity Press.

Subramaniam, N., Carey, P., Zaleha Abdul Rasid, S., Rahim Abdul Rahman, A., \& Khairuzzaman Wan Ismail, W. 2011. Management accounting and risk management in Malaysian financial institutions: An exploratory study. Managerial Auditing Journal, 26(7): 566-585.

Turner, K. L., \& Makhija, M. V. 2006. The role of organizational controls in managing knowledge. Academy of Management Review, 31(1): 197-217.

Tversky, A., \& Kahneman, D. 1992. Advances in prospect theory: cumulative representation of uncertainty. Journal of Risk and Uncertainty, 5(4): 297-323.

Vandenbosch, B. 1999. An empirical analysis of the association between the use of executive support systems and perceived organizational competitiveness. Accounting, Organizations and Society, 24(1): 77-92. 
Vaara, E., \& Whittington, R. 2012. Strategy-as-practice: taking social practices seriously. The Academy of Management Annals, 6(1): 285-336.

Whittington, R. 2006. Completing the practice turn in strategy research. Organization Studies, 27(5): 613-634.

Whittle, A., \& Mueller, F. 2010. Strategy, enrolment and accounting: the politics of strategic ideas. Accounting, Auditing \& Accountability Journal, 23(5): 626-646. 